Nathania Juliani Christy, Roswita Oktavianti: Pengaruh Komunikasi Persuasif Guru terhadap Motivasi Belajar Siswa Saat Pandemi COVID-19

\title{
Pengaruh Komunikasi Persuasif Guru terhadap Motivasi Belajar Siswa Saat Pandemi COVID-19
}

\author{
Nathania Juliani Christy, Roswita Oktavianti \\ nathania.915160014@stu.untar.ac.id, roswitao@fikom.untar.ac.id
}

Fakultas Ilmu Komunikasi Universitas Tarumanagara

\begin{abstract}
Communication between teachers and students is an important aspect in learning process, especially during this COVID-19 Pandemic. The learning process, which usually happens face-to-face in schools, is suddenly forced to shift to online learning at home to prevent spreading the virus. The study aims to determine whether there is an effect of teacher's persuasive communication on student's learning motivation during online learning and how much influence it has. This study uses the theory of persuasive communication principles and the theory of sources of motivation. The researcher uses quantitative method with a survey using 5-level Likert scale questionnaire. The population of this study is students of Methodist Banda Aceh junior high school with a sample of 112 respondents using simple random sampling technique. The result of the research is teacher's persuasive communication does effect on student's learning motivation during online learning. It was found that student's learning motivation was influenced about $67.6 \%$ by the teacher's persuasive communication, while the remaining $32.4 \%$ was influenced by other variables that are not examined by the researcher in this study.
\end{abstract}

Keywords: learning motivation, online learning, persuasive communication

\begin{abstract}
Abstrak
Komunikasi antara guru dan siswa merupakan aspek penting dalam pembelajaran khususnya saat pandemi COVID-19. Proses belajar yang biasanya terjadi secara tatap muka di sekolah, secara mendadak dipaksa beralih ke pembelajaran secara daring untuk mencegah penyebaran virus corona. Penelitian ini ingin mengetahui apakah ada pengaruh komunikasi persuasif guru terhadap motivasi belajar siswa selama pembelajaran daring serta seberapa besar pengaruh tersebut. Peneliti menggunakan pendekatan kuantitatif dengan metode survei menggunakan kuesioner online. Populasi dari penelitian ini adalah siswa/i SMP Methodist Banda Aceh dengan sampel yang diambil sebanyak 112 responden dan menggunakan teknik simple random sampling. Dari penelitian ini ditemukan bahwa ditemukan ada pengaruh komunikasi persuasif guru terhadap motivasi belajar siswa selama pembelajaran daring. Pengaruh tersebut sebesar $67,6 \%$, sementara sisanya $32,4 \%$ dipengaruhi oleh variabelvariabel lain.
\end{abstract}

Kata Kunci: komunikasi persuasif, motivasi belajar, pembelajaran daring

\section{Pendahuluan}

Pandemi coronavirus disease atau yang lebih sering disebut sebagai Pandemi Covid-19 di Indonesia berhasil membuat aktivitas belajar terpaksa harus dilakukan dari rumah menggunakan sarana video conference, digital documents, dan sarana daring lainnya untuk mencegah penyebaran virus (kemendikbud.go.id, 2020). Perubahan yang mendadak ini akhirnya menimbulkan banyak permasalahan seperti sulitnya terjalin komunikasi yang baik diantara guru, siswa dan orang tua, 
peningkatan rasa jenuh, stres dan juga kesulitan konsentrasi dalam belajar (Covid19.go.id, 2020). Kegiatan belajar daring akhirnya menjadi proses yang terlalu berat dan tidak menyenangkan sehingga siswa kehilangan motivasi untuk belajar.

Sekolah perlu menemukan cara untuk membangkitkan kembali motivasi belajar siswa di situasi pandemi Covid-19. Hal ini karena motivasi belajar yang rendah akan membuat tujuan dari pembelajaran tidak tercapai. Guru memegang peranan penting untuk dapat membuat siswa berkonsentrasi dalam belajar ataupun justru menarik diri dari kegiatan belajar, tergantung dari cara berkomunikasi (Sucia, 2017, p.112). Salah satu cara berkomunikasi guru yang dapat digunakan adalah dengan komunikasi persuasif. Komunikasi persuasif adalah penyampaian pesanpesan yang dilakukan oleh komunikator sedemikian rupa yang bertujuan untuk mengubah sikap, pendapat, atau perilaku komunikan (Effendy, dalam Damayanti, 2013). Dengan komunikasi persuasif yang tepat sasaran, siswa dapat merasa percaya diri untuk menjalankan pembelajaran daring sehingga terhindar dari rasa jenuh dan tidak termotivasi.

Penelitian mengangkat empat prinsip komunikasi persuasif menurut Littlejohn dan Jabusch (DeVito, dalam Karlinda, 2013, p.18-19) yaitu, prinsip partisipasi khalayak, prinsip inokulasi, prinsip pemaparan selektif dan prinsip besaran perubahan sebagai variabel independen. Variabel dependen dari penelitian ini adalah dua sumber motivasi (Atthabari, 2019, p.49-50), yaitu motivasi yang datang dari diri sendiri atau motivasi intrinsik dan motivasi yang dipengaruhi oleh rangsangan dari luar atau motivasi ekstrinsik.

Penelitian berfokus pada pembelajaran yang terjadi secara jarak jauh atau daring di masa Pandemi Covid-19. Menurut Sofyana \& Abdul (2019, dalam Handarini \& Wulandari, 2020). Pembelajaran daring adalah sistem pembelajaran yang dilakukan tanpa bertatap muka secara langsung dan menggunakan sarana yang dapat membantu pembelajaran meskipun dilakukan secara jarak jauh. Beberapa inovasi yang dapat dilakukan dalam pembelajaran daring adalah penggunaan Learning Management System (LSM), video conference dan juga melalui video learning (Gusty, dkk, 2020). Berdasarkan latar belakang tersebut, rumusan masalah penelitian ini adalah apakah terdapat pengaruh komunikasi persuasif guru terhadap motivasi belajar siswa selama pembelajaran daring, dan jika ada, seberapa besar pengaruh tersebut. Hipotesis alternatif dari penelitian ini adalah terdapat pengaruh komunikasi persuasif guru terhadap motivasi belajar siswa saat Pandemi Covid-19.

\section{Metode Penelitian}

Penelitian ini adalah penelitian kuantitatif dengan metode penelitian survei. Metode survei menggunakan kuesioner sebagai instrumen utama dalam pengumpulan data (Siyoto dan Sodik, 2015, p.20). Pendekatan kuantitatif merupakan jenis penelitian yang sistematis, terencana dan menuntut penggunaan angka serta pengumpulan dan penafsiran data. Dalam sebuah penelitian kuantitatif, terdapat variabel independen (variabel $\mathrm{X}$ ) dan variabel dependen (variabel Y). Variabel X dari penelitian ini adalah komunikasi persuasif yang dilakukan oleh tenaga pengajar. Variabel Y dari penelitian ini adalah motivasi belajar siswa. Populasi dari penelitian ini adalah SMP Methodist Banda Aceh. Untuk penarikan sampel, dilakukan teknik simple random sampling. Lalu digunakan pendekatan rumus Slovin untuk menentukan jumlah sampel yang digunakan. Dengan batas toleransi kesalahan 
sebanyak 5\%, didapatkan 112 responden untuk mewakili total populasi 155 siswa/i dari SMP Methodist Banda Aceh.

Data primer dari penelitian ini diambil dari instrumen kuesioner. Menurut Riyanto dan Hatmawan (2020, p.29), kuesioner adalah teknik pengumpulan data yang dilakukan dengan cara memberikan beberapa pertanyaan atau pernyataan kepada responden untuk dijawab. Kuesioner yang disebar kepada siswa/i SMP Methodist Banda Aceh berisi pernyataan-pernyataan yang berhubungan dengan empat prinsip komunikasi persuasif dan sumber dari motivasi belajar siswa. Penelitian ini menggunakan skala likert 5 tingkat dari Sangat Setuju (SS) sampai Sangat Tidak Setuju (STS) untuk memperoleh skor (Riyanto dan Hatmawan, 2020, p.23). Data sekunder atau data jadi dari penelitian ini diperoleh dari buku-buku serta jurnal terdahulu. Peneliti juga mengambil data dari sumber online yaitu website resmi pemerintah.

Teknik analisis data yang digunakan pada penelitian ini adalah uji koefisien korelasi yang digunakan untuk mengukur kekuatan hubungan antara kedua variabel dengan menggunakan Korelasi Pearson. Uji koefisien determinasi dilakukan untuk mengetahui besar persentase pengaruhnya. Peneliti juga melakukan analisis regresi sederhana untuk memprediksi nilai variabel $\mathrm{X}$ berdasarkan nilai variabel $\mathrm{Y}$ dengan persamaan $\mathrm{Y}=\mathrm{a}+\mathrm{bX}$ dan juga uji $\mathrm{T}$ atau uji hipotesis untuk mengetahui apakah variabel independen yaitu Komunikasi Persuasif (X) secara parsial memiliki pengaruh secara signifikan terhadap variabel dependen yaitu Motivasi Belajar Siswa (Y). Keabsahan data dilakukan dengan uji validitas dengan cara melihat angka pada kolom Corrected Item Total Correlation, uji reliabilitas dengan cara melihat nilai Cronbach's Alpha, dan uji normalitas dengan menggunakan One Sample Kolmogorov-Smirnov Test. Seluruh data diolah menggunakan software SPSS Statistics 20.0 for Windows.

\section{Hasil Temuan dan Diskusi}

Berdasarkan hasil penelitian, diketahui bahwa responden yang berada di kelas 1 SMP sebanyak 34 orang $(30,40 \%)$, kelas 2 SMP sebanyak 46 orang $(41,10 \%)$ dan kelas 3 SMP sebanyak 32 orang $(28,60 \%)$. Dari jumlah responden maka mayoritas responden merupakan siswa/i kelas 2 SMP. Dari hasil data kuesioner, sebanyak 64,3\% responden memilih aplikasi WhatsApp sebagai sarana pembelajaran daring yang paling disukai dibanding dengan Google Classroom, Zoom Cloud Meeting, Google Meet dan Ms Teams. Hasil olah data untuk pernyataan-pernyataan kuesioner terkait variabel $\mathrm{X}$ yaitu prinsip komunikasi persuasif adalah sebagai berikut.

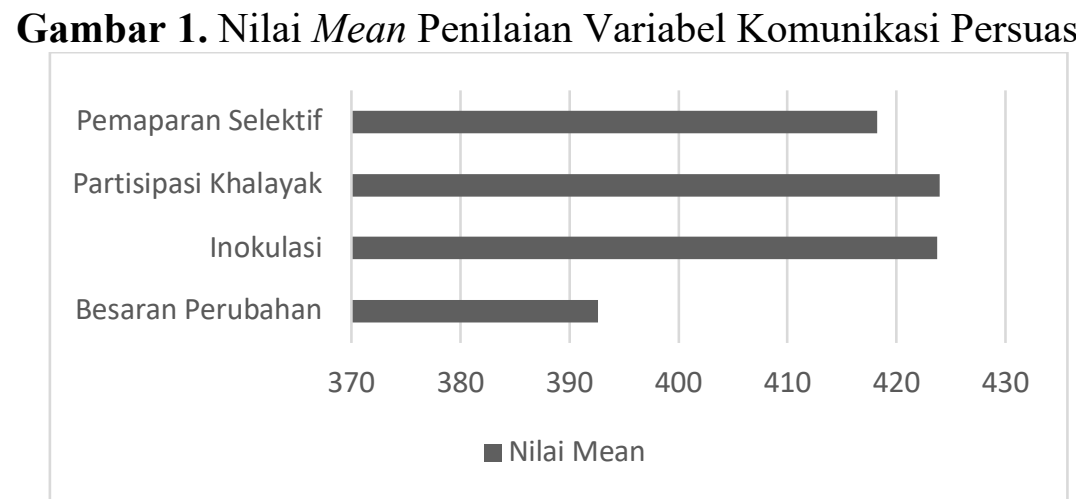

Sumber: Pengolahan Data Peneliti 
Gambar 1 menunjukkan bahwa dimensi Prinsip Partisipasi Khalayak merupakan dimensi tertinggi dalam variabel komunikasi persuasif dengan nilai mean sebesar 424. Menurut definisi Littlejohn dan Jabusch (Devito, dalam Karlinda, 2013) mengenai prinsip partisipasi khalayak, hal ini berarti komunikasi persuasif yang dilakukan guru terlihat dari partisipasi aktif dari siswa dalam pembelajaran. Contohnya seperti berinteraksi dengan guru selama pembelajaran dan mengerjakan tugas dari guru. Hasil olah data untuk pernyataan-pernyataan kuesioner terkait variabel Y yaitu sumber motivasi adalah sebagai berikut:

Gambar 2. Nilai Mean Penilaian Variabel Motivasi Belajar Siswa

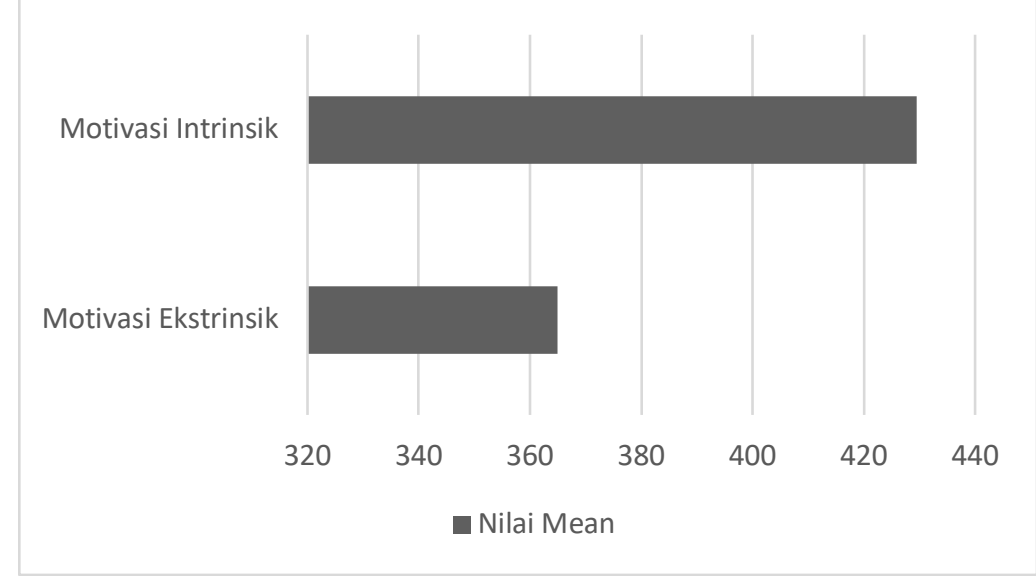

Sumber: Pengolahan Data Peneliti

Gambar 2 menunjukkan bahwa dimensi Motivasi Intrinsik merupakan dimensi tertinggi dalam variabel Motivasi Belajar Siswa dengan nilai mean sebesar 429,5. Hal ini menunjukkan bahwa siswa kerap mendapat motivasi dari dirinya sendiri dalam hal belajar karena memahami pentingnya belajar.

Hasil uji validitas terhadap 27 butir pernyataan kuesioner yang terdiri dari 17 butir pernyataan pada variabel komunikasi persuasif dan 10 butir pernyataan pada variabel motivasi belajar siswa dinyatakan semua valid karena nilai corrected item total correlation $>0,2$. Variabel $\mathrm{X}$ dinyatakan reliabel dengan nilai Cronbach's Alpha sebesar 0,900 dan nilai Cronbach's Alpha sebesar 0,872 untuk variabel Y. Berdasarkan hasil dari uji normalitas melalui SPSS 20 menunjukkan bahwa nilai signifikansi $0,734>0,5$, maka dapat disimpulkan bahwa nilai residual hasil data kuesioner merupakan distribusi normal.

Tabel 1. Hasil Koefisien Korelasi

\begin{tabular}{|cc|c|c|}
\hline & & $\begin{array}{c}\text { Komunikasi } \\
\text { Persuasif }\end{array}$ & $\begin{array}{c}\text { Motivasi } \\
\text { Belajar Siswa }\end{array}$ \\
\hline Komunikasi Persuasif & Pearson Correlation & 1 & $.822^{* *}$ \\
& Sig. (2-tailed) & & .000 \\
Motivasi Belajar & Pearson Correlation & $.822^{* *}$ & 112 \\
Siswa & Sig. (2-tailed) & .000 & 1 \\
& $\mathrm{~N}$ & 112 & 112 \\
\hline
\end{tabular}

**. Correlation is significant at the 0.01 level (2-tailed).

Sumber: Pengolahan Data Peneliti 
Nathania Juliani Christy, Roswita Oktavianti: Pengaruh Komunikasi Persuasif Guru terhadap Motivasi Belajar Siswa Saat Pandemi COVID-19

Tabel 1 menunjukkan hasil uji koefisien korelasi dari penelitian ini yaitu 0,822. Angka ini berada pada dimensi hubungan antar variabel yang sangat kuat. Artinya, kedua variabel ini saling berhubungan dengan kuat.

Tabel 2. Hasil Koefisien Determinasi

\begin{tabular}{|c|c|c|c|c|}
\hline Model & $\mathrm{R}$ & R Square & $\begin{array}{c}\text { Adjusted R } \\
\text { Square }\end{array}$ & $\begin{array}{c}\text { Std. Error of } \\
\text { the Estimate }\end{array}$ \\
\hline 1 & $.822^{\mathrm{a}}$ & .676 & .673 & 4.116 \\
\hline
\end{tabular}

a. Predictors: (Constant), Komunikasi Persuasif

Sumber: Pengolahan Data Peneliti

Tabel 2 menunjukkan hasil koefisien determinasi dari penelitian ini yakni sebesar 0,676. Berdasarkan hasil tersebut, dapat disimpulkan bahwa motivasi belajar siswa dipengaruhi sebesar $67,6 \%$ oleh kegiatan komunikasi persuasif guru, sementara sisanya $32,4 \%$ dipengaruhi oleh variabel lain yang tidak diteliti dalam penelitian ini.

Tabel 3. Hasil Analisis Regresi Sederhana

\begin{tabular}{|c|c|c|c|c|c|}
\hline \multirow{2}{*}{ Model } & \multicolumn{2}{|c|}{$\begin{array}{c}\text { Unstandardized } \\
\text { Coefficients }\end{array}$} & $\begin{array}{c}\text { Standardized } \\
\text { Coefficients }\end{array}$ & $\mathrm{t}$ & Sig. \\
\cline { 2 - 5 } & $\mathrm{B}$ & Std. Error & Beta & & \\
\hline \multirow{2}{*}{$1 \quad \begin{array}{c}\text { (Constant) } \\
\text { Komunikasi } \\
\text { Persuasif }\end{array}$} & -.962 & 2.407 & & -.400 & .690 \\
& .576 & .038 & .822 & 15.134 & .000 \\
\hline
\end{tabular}

Sumber: Pengolahan Data Peneliti

Tabel 3 menunjukkan hasil analisis regresi linear sederhana dan ditemukan persamaan $\mathrm{Y}=0,576 \mathrm{X}-0,962$, nilai signifikansi $0,000<$ probabilitas 0,05 .

Berdasarkan definisi dari komunikasi persuasif oleh pakar komunikasi, Andri Hasan (dalam Siregar, 2014), target dari komunikasi persuasif adalah afektif. Artinya komunikan tidak hanya sekedar tahu, tapi juga tergerak hatinya dan menimbulkan perasaan tertentu. Berdasarkan hasil olah data kuesioner, bentuk dari sikap afeksi siswa/i SMP Methodist Banda Aceh yang paling terlihat adalah ketertarikan belajar saat guru membahas topik yang disukai, keaktifan dalam mengerjakan tugas dan mengumpulkannya tepat waktu, serta bagaimana siswa mendengarkan nasehat guru dengan seksama dan dapat mempengaruhi kepercayaan siswa akan sesuatu. Dengan demikian, komunikasi persuasif dari guru dapat memberikan pengaruh terhadap motivasi belajar dari siswa selama pembelajaran daring di masa Pandemi Covid-19.

\section{Simpulan}

Penelitian yang dilakukan pada siswa SMP ini menunjukkan bahwa terdapat pengaruh antara komunikasi persuasif guru dengan motivasi belajar siswa saat pandemi COVID-19. Hubungan antara variabel komunikasi persuasif guru dan motivasi belajar siswa juga sangat kuat. Komunikasi persuasif guru dapat 
mempengaruhi motivasi belajar siswa sebanyak $67,6 \%$ selama pembelajaran daring dan sisanya $32,4 \%$ dipengaruhi oleh variabel lain yang tidak diteliti dalam penelitian ini.

Berdasarkan hasil uji hipotesis, dapat disimpulkan bahwa Ho ditolak dan Ha diterima, yang berarti terdapat pengaruh antara kegiatan komunikasi persuasif guru terhadap motivasi belajar siswa SMP Methodist Banda Aceh selama masa Pandemi COVID-19. Hal ini membuktikan bahwa komunikasi persuasif guru berperan penting dalam menunjang efektifitas pembelajaran. Peneliti menyarankan bagi peneliti lain yang ingin meneliti tentang motivasi belajar siswa selama pembelajaran daring bisa mencari variabel lain yang mampu mempengaruhi selain komunikasi persuasive guru.

\section{Ucapan Terima Kasih}

Peneliti mengucapkan terima kasih yang sebesar-besarnya kepada Fakultas Ilmu Komunikasi Universitas Tarumanagara dan kepada SMP Methodist Banda Aceh, terkhusus Kepala Sekolah SMP Methodist Banda Aceh yang telah mengizinkan penyelenggaraan penelitian ini. Terima kaish kepada para siswa/i sebagai yang telah bersedia mengisi kuesioner dengan baik dan jujur. Terima kasih juga kepada semua teman-teman yang sudah banyak membantu peneliti selama proses pengerjaan skripsi dan memberi banyak masukan serta dukungan moral.

\section{Daftar Pustaka}

Covid.go.id.

(2020).

https://covid19.go.id/storage/app/media/Materi\%20Edukasi/20200807pembelajaran-di-masa-covid-19-2.pdf diunduh tanggal 15 September 2020

Damayanti, A., Suprihatini, T., \& Pradekso, T. (2013). Pengaruh Komunikasi Persuasif Guru dan Motivasi Belajar Siswa Terhadap Prestasi Siswa Pada Mata Pelajaran Bahasa Jawa. Interaksi Online, 2(2). https://ejournal3.undip.ac.id/index.php/interaksi-online/article/view/2389 diunduh tanggal 16 September 2020

Gusty, dkk. (2020). Belajar Mandiri: Pembelajaran Daring di Tengah Pandemi Covid-19. Medan: Yayasan Kita Menulis.

Handarini, O. I., \& Wulandari, S. S. (2020). Pembelajaran Daring Sebagai Upaya Study From Home (SFH) Selama Pandemi Covid 19. Jurnal Pendidikan Administrasi Perkantoran (JPAP), 8(3), 496-503. https://journal.unesa.ac.id/index.php/jpap/article/view/8503 diunduh tanggal 3 Oktober 2020

Karlinda, D. (2013). Teknik Komunikasi Persuasif Untuk Meningkatkan Motivasi Belajar Siswa Kelas X Program Keahlian Administrasi Perkantoran di SMK Muhammadiyah 2 Yogyakarta. (Skripsi, Universitas Negeri Yogyakarta). https://eprints.uny.ac.id/16899/ diunduh tanggal 2 Oktober 2020

Kemendikbud.go.id (2020). https:/www.kemdikbud.go.id/main/blog/2020/03/semendikbud-pembelajaran-secara-daring-dan-bekerja-dari-rumah-untukmencegah-penyebaran-covid19 diunduh tanggal 15 September 2020

Riyanto, S., \& Hatmawan, A. A. (2020). Metode Riset Penelitian Kuantitatif Penelitian Di Bidang Manajemen, Teknik, Pendidikan Dan Eksperimen. Yogyakarta: Deepublish. 
Nathania Juliani Christy, Roswita Oktavianti: Pengaruh Komunikasi Persuasif Guru terhadap Motivasi Belajar Siswa Saat Pandemi COVID-19

Siregar, R. H. (2014). Bentuk dan Teknik Komunikasi Ketua Untuk Meningkatkan Disiplin Mahasiswa di Sekolah Tinggi Agama Islam As-Sunnah Kabupaten Deli Serdang (Doctoral dissertation, Pascasarjana UIN Sumatera Utara). http://repository.uinsu.ac.id/1705/ diunduh tanggal 2 Oktober 2020

Siyoto, S., \& Sodik, M. A. (2015). Dasar Metodologi Penelitian. Yogyakarta: Literasi Media Publishing.

Sucia, V. (2017). Pengaruh Gaya Komunikasi Guru Terhadap Motivasi Belajar Siswa. Komuniti: Jurnal Komunikasi Dan Teknologi Informasi, 8(2), 112126. http://journals.ums.ac.id/index.php/komuniti/article/view/2942 diunduh tanggal 16 September 2020

Sugiyono, (2012). Metode Penelitian Kuantitatif Kualitatif dan R\&D. Bandung: Alfabeta. 